This document is the Accepted Manuscript version of a Published Work that appeared in final form in The Journal of Organic Chemistry 84(10) : 6298-6311 (2019), copyright (C) 2019 American Chemical Society after peer review and technical editing by the publisher. To access the final edited and published work see https://doi.org/10.1021/

$\underline{\text { acs.joc. } 9 \mathrm{~b} 00646}$

\title{
Synthesis of Indenes by the Tandem Gold(I)-Catalyzed Claisen Rearrangement/Hydroarylation Reaction of Propargyl Vinyl Ethers
}

\author{
Antonia Rinaldi, ${ }^{\dagger}$ Vittoria Langé, ${ }^{\dagger}$ Enrique Gómez-Bengoa, ${ }^{\ddagger}$ Giovanna Zanella, ${ }^{\ddagger}$ Dina Scarpi, ${ }^{\dagger}, *$ \\ Ernesto G. Occhiato ${ }^{\dagger}, *$ \\ †Dipartimento di Chimica "U. Schiff”, Università degli Studi di Firenze, Via della Lastruccia 13, \\ 50019, Sesto Fiorentino (FI), Italy. \\ *Departamento de Química Orgánica I, Universidad del País Vasco / UPV-EHU, Manuel de \\ Lardizabal 3, Donostia-San Sebastián, Spain-20018.
}

\begin{abstract}
The tandem gold(I)-catalyzed propargyl Claisen rearrangement/hydroarylation reaction of suitable propargyl vinyl ethers, followed by in situ reduction of the resulting carbonyl group, provides functionalized indenes in good to excellent yields. The reaction occurs at room temperature in dichloromethane in the presence of $3 \mathrm{~mol} \%[\mathrm{IPrAuCl}] / \mathrm{AgBF}_{4}$ as the best catalytic system. With phosphine ligands no cyclization of the allene intermediate instead occurs. A variety of substituents and functional groups present on the substrate are tolerated. The effect of the aryl ring substituents and the results of a DFT computational study suggest that the final hydroarylation is the rate determining step of this cascade process. Further in situ chain elongation, prior final work up of the tandem process, can be carried out by Wittig olefination of the aldehyde functionality, thus incrementing the diversity of the products obtained.
\end{abstract}

\section{Introduction}

The development of efficient methods for the synthesis of indenes (benzocyclopentadienes)[1] continues to attract interest among the organic chemists' community as these compounds show a variety of biological activities, including antitumor, anticonvulsant, antiallergic, antihypercholesterolemic, fungicidal, herbicidal, and antimicrobial activities.[2] The indene framework is also found in natural products (Figure 1),[3] and it finds application in material science,[4] and in the preparation of ligands for metal complexes, e.g. ligands for tailored metallocene complexes used to catalyze olefin polymerization.[5]

Metal-catalysis has been widely exploited to build this important carbocycle through a variety of processes,[1a, 1k-w] including those based on the [1,2]- or [1,3]-rearrangement and carbocyclization of propargylic esters and carbonates.[6] Given the high efficiency of $\mathrm{Au}(\mathrm{I})$ in activating triple bonds, [7] gold-catalysis has been exploited, too, for the synthesis of indenes by such an approach,[8ab],[9] while other methods based on gold(I)-catalysis include the carbocyclization of 1-alkynyl-2(methoxymethyl)benzene derivatives,[8c-e], the carbocyclization of 1,5- and 1,6-enynes embodying an aryl ring, [8f-j] the $\mathrm{C}_{\mathrm{sp} 3}-\mathrm{H}$ bond activation in diarylacetylene derivatives, [8k] the formal $(3+2)$ cycloaddition between allenes and aryl gold(I)-carbenes,[81] tandem transformations of 1,5-diynes embodying an aryl ring via a gold-vinylidene intermediate,[8m-o] and a few other multicomponent processes.[8p-r]

We have recently reported that suitably substituted propargyl vinyl ethers $\mathbf{1}$ undergo a propargyl Claisen rearrangement[10] followed by a Nazarov cyclization when subjected to gold(I)-catalysis, which efficiently provided functionalized cyclopentadienes 2 fused with various $N$-hetero- and 
carbocycles.[11] [Schema 1, (a)] In this process, the gold-catalyzed [3,3]-rearrangement generates a gold-allene complex which, once formed, immediately undergoes the $4 \pi$-electrocyclization plausibly via the corresponding pentadienyl cation to form the final product.[12] While in the rearrangement of propargylic esters the final products are cyclopentenones o cyclopentadienyl alkanoates,[9] the tandem propargyl Claisen rearrangement/Nazarov reaction provides cyclopentadienes bearing, on one side chain, an aldehyde group which could be subjected to further in situ elaboration for chain elongations. Given the importance of indenes, and in continuation of our study on gold-catalyzed rearrangement processes involving propargyl alcohol derivatives,[13] we decided to evaluate whether the same approach could be used for the construction of such important ring systems by exploiting the rearrangement of 3-aryl-substituted propargyl vinyl ethers 3 [Scheme 1, (b)]. Gold-catalyzed cascade processes which form indenes, involving the [3,3]-rearrangement of propargylic ester derivatives followed by cyclization of the gold-allene complex intermediate,[8a-b] as well as the direct $\mathrm{Au}(\mathrm{I})$-catalyzed hydroarylation of allenes, [8b] have been reported. However, the achievement of our synthetic objective was not so obvious as the final cyclization involves the disruption of the aromaticity of the phenyl ring, with the consequence that the optimal conditions (gold ligand, temperature, counterion) for the initial Claisen rearrangement could be unsuitable for the subsequent step of the cascade process and vice versa. In this paper we report on an experimental and computational study of the tandem gold(I)-catalyzed Claisen rearrangement/hydroarylation cyclization of 3-aryl-substituted propargyl vinyl ethers and show that it efficiently provides polyfunctionalized indenes. Moreover, we demonstrate that further in situ elaboration of the aldehyde functionality is possible by Wittig olefination, thus enlarging the variety of products which can be obtained by this methodology.

\section{Results and Discussion}

The synthesis of the substrates (Scheme 2) for the gold-catalyzed reaction was carried out by treatment of the corresponding propargylic alcohols 5 with ethyl vinyl ether in the presence of

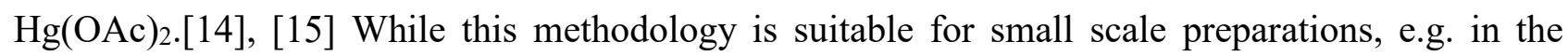
evaluation of the scope of the gold-catalyzed tandem process, we looked for an alternative approach to vinyl ethers 6 when these were needed in larger amount, in order to avoid the use of the mercury salt.[16] Out of the many approaches we experimented, the best is depicted in Scheme 3. As shown, converting 5a into the corresponding acetate and then treating with $\mathrm{InCl}_{3}$ in nitromethane at $50{ }^{\circ} \mathrm{C}$ in the presence of 2-bromo-1-ethanol, provided bromide 7a in 78\% yield over the two steps.[17] The next elimination step was carried out by treatment of $\mathbf{7} \mathbf{a}$ with a strong base ( $t$-BuOK in toluene) which provided model compound 6a in 91\%.[18]

We used this substrate to find the best reaction conditions for the gold(I)-catalyzed process and the results of the screening of various gold(I)-catalysts and gold(I)-precatalyst/silver salt combinations are reported in Table 1 . The reactions were carried out by adding a solution of the substrate in DCM to a solution of the catalyst ( $3 \mathrm{~mol} \%$ ) generated by mixing the gold and silver salts in the same solvent at $25{ }^{\circ} \mathrm{C}$. The $\left[\mathrm{Ph}_{3} \mathrm{PAu}\right]^{+} \mathrm{BF}_{4}^{-}$and $\left[\mathrm{Ph}_{3} \mathrm{PAu}\right]^{+} \mathrm{TfO}^{-}$catalysts (entries 1 and 2 ) have been shown to catalyze the Claisen rearrangement of propargyl vinyl ethers.[10a] With 3 mol \% of these catalysts in $\mathrm{CH}_{2} \mathrm{Cl}_{2}$ substrate $6 \mathbf{a}$ was quickly (less than $30 \mathrm{~min}$ ) and quantitatively converted into allene 9a.[19] However, we did not observe even traces of indene 8a in the crude reaction mixtures by prolonging the reaction times. Gold salts with $\mathrm{Ph}_{3} \mathrm{P}$ and electron-rich phosphine ligands were all competent catalysts in the tandem Claisen rearrangement/Nazarov cyclization of enynyl vinyl ethers,[11] but as 
it is evident from entries 1-2 and 4-5, they seem unable to promote the final hydroarylation step with substrate 6a. Instead, with the NHC (NHC $=$ N-heterocylic carbene) ligand IPr and various anions (entries 6-10) we always observed the formation of indene 8a. The [IPrAuCl]/AgBF 4 catalytic system was the best in the gold(I)-catalyzed formation of indene from propargylic acetates, [8b] and the same occurred with our substrate (entry 8). [20] With $3 \mathrm{~mol} \%$ of this catalyst we observed (by ${ }^{1} \mathrm{H} \mathrm{NMR}$ ) the immediate (less than $5 \mathrm{~min}$ ) conversion of the substrate into allene 9a, half of which already cyclized to indene $8 \mathbf{a}(\mathbf{8 a} / 9 \mathbf{a}$ ratio $=1: 1$ after $5 \mathrm{~min})$. After $15 \mathrm{~min}$, the ratio was $3.2: 1$ and in 25 minutes the reaction was complete. With $1 \mathrm{~mol} \%$ of the catalyst the reaction was complete in $3 \mathrm{~h}$. Commercial $\left[\mathrm{IPrAu}\left(\mathrm{CH}_{3} \mathrm{CN}\right)\right]^{+} \mathrm{BF}_{4}^{-}$(entry 9) catalyzed the reaction, too, ruling out any role of the silver salt in the hydroarylation step. On the other hand, $\mathrm{AgBF}_{4}$ alone (entry 16) was able to catalyze the Claisen rearrangement, but not the cyclization, and similarly in the presence of the IPrAuCl salt alone (entry 15) only the [3,3]-rearrangement occurred.

We tested other NHC gold complexes (entries 11-14) and quite surprisingly, among these, only the SIPr ligand was effective, although the reaction was slightly slower than with IPr ligand (the 8a/9a ratio was 1:1 after $15 \mathrm{~min}$ ).[21] With $\mathrm{ICy}$, ItBu, and IMes ligands only allene 9a was formed. Interestingly, in the $\mathrm{Au}(\mathrm{I})$-catalyzed tandem [3,3]-rearrangement-hydroarylation of propargylic acetates to form indenes, other NHC ligands were able (although not as efficiently as IPr) to promote the hydroarylation step.[8b]

Having found the best reaction conditions, these were used to evaluate the scope with 3-arylsubstituted propargyl vinyl ethers bearing various groups $\left(\mathrm{R}^{3}\right)$ on the aromatic ring and substituents $\left(\mathrm{R}^{1}, \mathrm{R}^{2}\right.$ ) on the carbynolic position (Scheme 4). To avoid both partial degradation of aldehydes 8 and double migration to the exocyclic position during chromatography on silica gel (which generates $\alpha, \beta$ unsaturated aldehydes), the reaction products were reduced in situ to the corresponding alcohols $\mathbf{1 0}$ by $\mathrm{NaBH}_{4}$ after dilution of the dichloromethane solution with $\mathrm{MeOH}$ (method A).[22] As an alternative, upon completion of the reaction, the crude aldehydes were isolated after an aqueous workup, dissolved in $\mathrm{MeOH}$ and then reduced (method B). By using the former procedure (method A), simple indene 10a was obtained in $80 \%$ yield after chromatography. Electron-donor groups on the aromatic ring made the reaction faster and, with the exception of the $o$-methyl substituted substrate $\mathbf{6 c}$, which reacted in $1.5 \mathrm{~h}$, alcohols $\mathbf{1 0 b}-\mathbf{1 0 f}$ were all obtained in $15 \mathrm{~min}$. $m$-Methyl- and $m$-methoxysubstituted substrates (6d and $\mathbf{6 f}$, respectively) of course provided a mixture of isomers deriving from ring closure at the ortho and para position. However, in the case of the $m$-methoxy-substituted compound, attack to the para position prevailed (86:14 ratio in the crude reaction mixture) and pure isomer 10f could be isolated by chromatography in good yield.[23a] With aromatic rings bearing amino- and alkoxy-substituted methyl groups $(\mathbf{6 g}$ and $\mathbf{6 h}$, respectively), the reaction proceeded smoothly, too, providing alcohols $10 \mathrm{~g}$ and $\mathbf{1 0 h}$ in good yield (62 and 75\% yield, respectively). In the case of $\mathbf{6} \mathbf{h}$, the reaction was carried out with the commercial [ $\left.\mathrm{IPrAuCH}_{3} \mathrm{CN}\right] \mathrm{BF} 4$ and, as for the model compound 6a, it was just slightly slower than with the [IPrAuCl]/AgBF 4 catalytic system. The latter, as well as the preformed catalyst, were used to carried out the reaction with the propargyl vinyl ether bearing a dioxolane moiety in para position $(\mathbf{6 i})$. The reaction was slow ( $2 \mathrm{~h}$ for a complete conversion of the allene intermediate) and in both case we observed an almost complete trans-acetalization during the gold(I)-catalyzed step. Thus compound 10i could be obtained in $63 \%$ yield after chromatography.[24] 
Table 1. Optimization of the reaction conditions ${ }^{\text {a }}$
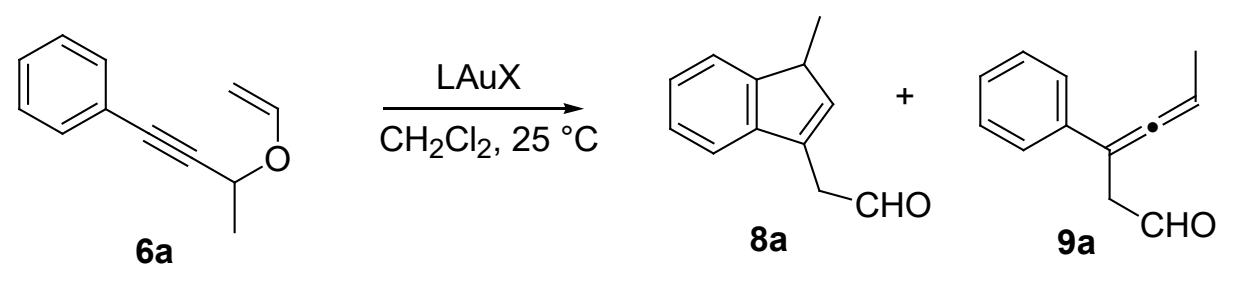

\begin{tabular}{|c|c|c|c|c|c|}
\hline entry & catalyst $^{\mathrm{b}}$ & time ( $\mathrm{min})$ & $\begin{array}{c}6 a \\
(\%)^{c}\end{array}$ & $\begin{array}{c}8 a \\
(\%)^{\mathrm{c}}\end{array}$ & $\begin{array}{c}9 a \\
(\%)^{\mathrm{c}}\end{array}$ \\
\hline 1 & {$\left[\mathrm{Ph}_{3} \mathrm{PAuCl}\right] / \mathrm{AgBF}_{4}$} & 30 & - & - & 100 \\
\hline 2 & {$\left[\mathrm{Ph}_{3} \mathrm{PAuCl}\right] / \mathrm{AgOTf}$} & 30 & - & - & 100 \\
\hline 3 & {$\left[\left(p-\mathrm{CF}_{3} \mathrm{C}_{6} \mathrm{H}_{4}\right)_{3} \mathrm{PAuCl}\right] / \mathrm{AgOTf}$} & 30 & $-d$ & - & - \\
\hline 4 & ${ }^{t} \mathrm{Bu}_{3} \mathrm{PAuNTf}{ }_{2} \mathrm{e}$ & 30 & - & - & 100 \\
\hline 5 & {$\left[\mathrm{Cy}_{3} \mathrm{PAuCl}\right] / \mathrm{AgOTf}$} & 30 & - & - & 100 \\
\hline 6 & {$[\mathrm{IPrAuCl}] / \mathrm{AgSbF}_{6}$} & 30 & - & $100^{f}$ & - \\
\hline 7 & {$[\mathrm{IPrAuCl}] / \mathrm{AgOTf}$} & 40 & - & $100^{f}$ & - \\
\hline 8 & {$[\mathrm{IPrAuCl}] / \mathrm{AgBF}_{4}$} & 25 & - & 100 & - \\
\hline 9 & $\operatorname{IPrAu}\left(\mathrm{CH}_{3} \mathrm{CN}\right) \mathrm{BF}_{4}{ }^{\mathrm{e}}$ & 60 & - & 100 & - \\
\hline 10 & $\operatorname{IPrAuNTf} f_{2}{ }^{\mathrm{e}}$ & 120 & - & 50 & 50 \\
\hline 11 & {$[\mathrm{SIPrAuCl}] / \mathrm{AgBF}_{4}$} & 55 & - & 100 & - \\
\hline 12 & {$[\mathrm{ICyAuCl}] / \mathrm{AgBF}_{4}$} & 55 & - & - & 100 \\
\hline 13 & {$[\mathrm{ItBuAuCl}] / \mathrm{AgBF}_{4}$} & 55 & - & - & 100 \\
\hline 14 & {$[\mathrm{IMesAuCl}] / \mathrm{AgBF}_{4}$} & 55 & $78^{\mathrm{g}}$ & - & 22 \\
\hline 15 & $\mathrm{IPrAuCl}$ & 55 & - & - & 100 \\
\hline 16 & $\mathrm{AgBF}_{4}$ & 60 & - & - & 100 \\
\hline
\end{tabular}

${ }^{a}$ Conditions: Reactions carried out on $0.2-0.3 \mathrm{mmol}$ of $6 \mathbf{6}$ in $\mathrm{CH}_{2} \mathrm{Cl}_{2}(0.05 \mathrm{M})$ at $25{ }^{\circ} \mathrm{C}$ under $\mathrm{N}_{2}$ atmosphere. ${ }^{b}$ Prepared by mixing the silver salt $(3 \mathrm{~mol} \%)$ and the gold chloride $(3 \mathrm{~mol} \%)$ in $\mathrm{CH}_{2} \mathrm{Cl}_{2}$ before addition of the substrate unless otherwise noted. $\mathrm{IPr}=1,3-$ bis(diisopropylphenyl)imidazol-2-ylidene, $\operatorname{SIPr}=$ 1,3-bis(2,6-diisopropylphenyl)-4,5-dihydroimidazol-2-ylidene), IMes = 1,3bis(2,4,6-trimethylphenyl)imidazol-2-ylidene), ItBu =1,3-di-t-butylimidazol-2-ylidene, ICy = 1,3-bis(cyclohexyl)imidazol-2-ylidene. ${ }^{c}$ Relative amount determined by ${ }^{1} \mathrm{H}$ NMR of the crude reaction mixture. ${ }^{d}$ Complete degradation of the starting material. ${ }^{e}$ Commercially available. ${ }^{f}$ Some degradation of the starting material occurred. ${ }^{g}$ Devinylation of 6 a to alcohol $5 \mathbf{a}$ occurred.

As expected on the basis of the above results, which suggest that the hydroarylation could be the rate determining step of the process (see later), the hydroarylation of the allene intermediate was in fact very slow with electron-withdrawing groups on the aromatic ring $(\mathbf{6 j}-\mathbf{6 l})$. In two cases $(\mathbf{6 k}$, bearing a $m$-F group, and 61, bearing a $p-\mathrm{CO}_{2} \mathrm{Me}$ group) either the long reaction times or the heating led to an almost equimolar mixture of isomers as a consequence of the shift of the double bond to the position 1 in the five-membered ring. Such an isomerization could be observed, to a very minor extent and regardless the presence or absence of a silver salt in the reaction mixture, also for other substrates for which, however, the adoption of method B allowed us to overcome the problem.[25] As in the case of the $m$-OMe-substituted substrate, also with $m$-F-substituted propargyl vinyl ether $6 \mathbf{k}$ the ring closure occurred predominantly ( $85 \%$ by ${ }^{1} \mathrm{H}$ NMR analysis of the crude reaction mixture) at the para position.[23b]

Finally, a few substrates with different substitution at the carbynolic position were evaluated and in all cases the reaction provided the target compounds (10m-p) in good to excellent yield. Benzylsubstituted indene 10n, however, which was obtained isomerically almost pure (95\%) from 6n after 
$3 \mathrm{~h}$ in the presence of $6 \mathrm{~mol} \%$ of the catalyst, underwent a slight double bond isomerization during the chromatography on silica gel and it was eventually obtained as a 9:1 mixture of isomers. With the gem-dimethyl substituted substrate 6o, because of the double substitution at the propargylic moiety, the reaction was slower $(3.5 \mathrm{~h})$ than with the model substrate 6a but provided the target compound $\mathbf{1 0 0}$ in an excellent 93\% yield. Similarly, the reaction of $\mathbf{6 p}$ was slow (16 h) and it was carried out in the presence of $6 \mathrm{~mol} \%$ of the catalyst, but it nevertheless provided compound 10p in $92 \%$ yield.

The only substrates which seem unsuitable for this gold(I)-catalyzed cascade process are those bearing an aryl ring at the carbynolic position (Scheme 5). Simple phenyl substituted propargyl vinyl ether $\mathbf{6 q}$, under various conditions, always quantitatively provided the corresponding allene 9q. We thought the lack of reactivity could be due to the stabilization by the phenyl ring of the positively charged gold(I)-complex intermediate [Scheme 1, (b)] making it less reactive, but the result obtained with dichloro-substituted substrate 6r (Scheme 5) instead suggests that it is either the greater stability of the aryl- substituted allene intermediates or the steric hindrance in the ring closure step by the aryl ring the possible reason.

A plausible mechanism for the tandem Claisen/hydroarylation reaction and the energies calculated relative to complex II are reported in Scheme 6.[26] Upon coordination of the triple bond to the cationic gold(I) complex, a very fast [3,3]-rearrangement of II occurs and conversion of the substrate into allene $\mathbf{V}$ is immediate. This is experimentally observed for all types of substrates suggesting that the Claisen rearrangement is not the rate determining step of the process. The calculated transition state energies for the rearrangement steps (TS1 and TS2) are in fact low with both $\mathrm{IPr}$ and $\mathrm{Ph}_{3} \mathrm{P}$ ligands $(<10-12 \mathrm{kcal} / \mathrm{mol})$, whereas the ring closure of allene-gold(I) complex $\mathbf{I V}$, which is in equilibrium with the free allene $\mathbf{V}$, presents a higher barrier $(17.9$ and $17.8 \mathrm{kcal} / \mathrm{mol})$ and thus is the rate determining step. When the cyclization is slow or does not take place, allene $\mathbf{V}$ can be isolated. The cyclization step takes place according to a classic electrophilic aromatic substitution to form VI and during this step a partial positive charge develops on the aromatic ring (TS3), which explains the effect of the substituents we observed when assessing the scope of the reaction. After proton elimination from $\mathrm{C} 7 \mathrm{a}$ (to restore aromaticity) and protodeauration of VII, indene VIII is eventually formed. We carried out an experiment with deuterated [D]-6a (Scheme 7) and found out that all deuterium was incorporated in the product at position $\mathrm{C} 1$, meaning that, contrarily to what observed in the tandem Claisen/Nazarov reaction [Scheme 1, (a)] we have recently studied, no [1,2]-H shift from position 1 to position 2 occurs.[11] Another important difference with the tandem Claisen/Nazarov process is that we were never able to observe (and isolate) the allene intermediates in that case, as the cyclization was a fast step, especially with carbocyclic substrates.[11]. Two important points in the present cascade process are the role of the $\mathrm{BF}_{4}{ }^{-}$counterion and the effect $\mathrm{IPr}$ gold(I)-ligand, which together form the best combination. Tetrafluoroborate is a weakly coordinating anion[27] and this could favor coordination of $\mathrm{LAu}^{+}$cationic complex to allene $\mathbf{V}$ to re-generate allene-gold complex IV (e.g. compare entries 9 and 10, as well as 7 and 8 in Table 1). Since the calculated energies (Scheme 6) are almost the same for both $\mathrm{IPr}$ and $\mathrm{Ph}_{3} \mathrm{P}$ ligands, explaining the efficiency of the NHC gold ligand compared to the phosphine ligands, with which we never observe ring closure of the allene $\mathbf{V}$ intermediates, is more difficult. It has been suggested that, in the rearrangement of a model propargyl acetate to form the corresponding allene, the latter is the resting state with a NHC ligand (IMe) and that allene coordination to gold is favored with the IMe ligand compared to a phosphine.[9d] We calculated the energies associated to the dissociation equilibrium 
of complex IV (Scheme 8) and found that the phosphine ligand is able to stabilize more efficiently the $\mathrm{LAu}^{+}$species, as the uphill energy is only $+3.9 \mathrm{kcal} / \mathrm{mol}$ compared with $+7.3 \mathrm{kcal} / \mathrm{mol}$ for the NHC carbene. Thus the equilibrium is more shifted to the left with the latter ligand with which the formation of allene-gold(I) complex intermediate $\mathbf{I V}$ from allene $\mathbf{V}$ is more favored. The reason why, a part from SIPr, the other NHC catalysts are unable to promote cyclization, is instead unclear at the moment.

Finally, to demonstrate that aldehyde intermediates $\mathbf{8}$ can be directly employed just after their formation for further chain elongation without prior work-up of the gold-catalyzed step, we studied the Wittig reaction of $\mathbf{8 0}$ and $\mathbf{8 p}$ with selected phosphorus ylides (Scheme 9). The reactions were carried out by transferring by syringe the dichloromethane solution containing the crude aldehyde to a THF solution of the preformed ylide at $0{ }^{\circ} \mathrm{C}$ and leaving under stirring until complete consumption of 8. With simple $\mathrm{Ph}_{3} \mathrm{P}=\mathrm{CH}_{2}$ the reaction led to the terminal olefin 11 in $70 \%$ yield after chromatography. No isomerization of the double bonds was observed. Similarly, the reaction occurred quantitatively with a substituted ylide prepared from $n$-hexylphosphonium iodide, which provided cis olefins 12 in $80 \%$ yield. Finally, after rearrangement and cyclization of $\mathbf{6 p}$, the crude aldehyde 8p was reacted with ylide 13, prepared from the corresponding commercial phosphonium bromide, which furnished compound $\mathbf{1 4}$ in $71 \%$ yield.

\section{Conclusions}

In conclusion, the tandem gold(I)-catalyzed propargyl Claisen rearrangement/hydroarylation reaction of aryl-substituted propargyl vinyl ethers is an efficient way to obtain functionalized indenes. The reaction occurs at room temperature in dichloromethane in the presence of $[\mathrm{IPrAuCl}] / \mathrm{AgBF} 4$ as the best catalytic system for both the propargyl Claisen rearrangement and the subsequent allene cyclization (the hydroarylation step). Instead, with phosphine ligands no cyclization of the allene intermediate occurs, which is probably due to the higher stabilization of the free cationic gold(I) in the equilibrium involving coordination/decoordination of the allene intermediate to gold(I) as suggested by DFT computations. Various groups and substituents on the aryl ring and at the carbynolic position of the propargyl vinyl ether are tolerated. The effect of the substituents on the aryl ring suggests that the final hydroarylation is the rate determining step of this cascade process with a calculated free activation energy of about $18 \mathrm{kcal} / \mathrm{mol}$ for both the NHC and phosphine ligand. Further functionalization can be achieved in situ prior final work of the tandem process by a chain elongation carried out by Wittig reaction on the aldehyde functionality, thus incrementing the diversity of the products obtained.

Acknowledgments. Financial support from University of Florence is acknowledged. Dr. Alessandro Pratesi is acknowledged for technical assistance. Ente Cassa di Risparmio di Firenze is acknowledged for granting a $400 \mathrm{MHz}$ NMR instrument. G. Zanella and E. Gómez-Bengoa thank the European Funding Horizon 2020-MSCA (ITN-EJD CATMEC 14/06-721223) and also SGiker (UPV/EHU) for human and technical support.

\section{References and Notes}


1) The synthesis of indenes has been recently reviewed: (a) Gabriele, B.; Mancuso, R.; Veltri, L. Chem. - Eur. J. 2016, 22, 5056-5094. See also: (b) Qiu, G.; Wu, J. Synlett 2014, 25, 2703-2713. Selected recent syntheses not involving transition metal catalysis: (c) Kotipalli, T.; Hou, D.-R. Org. Lett. 2018, 20, 4787-4790. (d) Yaragorla, S.; Khan, T. Org. Biomol. Chem. 2018, 16, 7920-7925. (e) Zou, H.; Li, Y.; Yang, X.; Xiang, J.; Li, J. J. Org. Chem. 2018, 83, 8581-8588. (f) Jayaram, V.; Sridhar, T.; Sharma, G. V. M.; Berrée, F.; Carboni, B. J. Org. Chem. 2017, 82, 1803-1811. (g) Chan, C.-K.; Hsueh, N.-C.; Tsai, Y.-L.; Chang, M.Y. J. Org. Chem. 2017, 82, 7077-7084. (h) García-García, P.; Sanjuán, A. M.; Rashid, M. A.; Martínez-Cuezva, A.; Fernández-Rodríguez, M. A.; Rodríguez, F.; Sanz, R. J. Org. Chem. 2017, 82, 1155-1165. (i) Zhang C.; Lupton, D. W. Org. Lett. 2017, 19, 4456-4459. (j) Mao, H.; Kim, D. W.; Shin, H. Y.; Song, C. E.; Yang, J. W. Org. Biomol. Chem. 2017, 15, 13551362. (j) Iakovenko, R. O.; Kazakova, A. N.; Boyarskaya, I. A.; Gurzhiy, V. V.; Avdontceva, M. S.; Panikorovsky, T. L.; Muzalevskiy, V. M.; Nenajdenko, V. G.; Vasilyev, A. V. Eur. J. Org. Chem. 2017, 37, 5632-5643. Selected recent syntheses involving transistion metal catalysis: (k) Zhu, X.-T.; Lu, Q.-L.; Wang, X.; Zhang, T.-S.; Hao, W.-J.; Tu, S.-J.; Jiang, B. J. Org. Chem. 2018, 83, 9890-9901. (1) Pei, C.; Rong, G.-W.; Yu, Z.-X.; Xu, X.-F. J. Org. Chem. 2018, 83, 13243-13255. (m) Barroso, R.; Paraja, M.; Cabal, M.-P.; Valdé, C. Org. Lett. 2017, 19, 4086-4089. (n) Tang, H.-J.; Zhang, Y.-F.; Jiang, Y.-W.; Feng, C. Org. Lett. 2018, 20, 5190-5193. (o) Wang, X.; Xiong, W.; Huang, Y.; Zhu, J.; Hu, Q.; Wu, W.; Jiang, H. Org. Lett. 2017, 19, 5818-5821. (p) Querard, P.; Li, C.-J. Org. Biomol. Chem. 2018, 16, 8042-8047. (q) Niharika, P.; Satyanarayana, G. Eur. J. Org. Chem. 2018, 971-979. (r) Philipps, A. R.; Blümel, M.; Dochain, S.; Hack, D.; Enders, D.Synthesis 2017, 49, 1538-1546. (s) Martin, M. C.; Sandridge, M. J.; Williams, C. W.; Francis, Z. A.; France, S. Tetrahedron, 2017, 73, 4093-4108. (t) Jayaram, V.; Sridhar, T.; Sharma, G. V. M.; Berrée, F.; Carboni, B. J. Org. Chem. 2017, 82, 1803-1811. (u) Jana, A.; Misztal, K.; Żak, A.; Grela, K. J. Org. Chem. 2017, 82, 4226-4234. (v) Chan, C.-K.; Hsueh, N.-C.; Tsai, Y.-L.; Chang, M.-Y. J. Org. Chem. 2017, 82, 7077-7084. (w) Bai, D.; Jia, Q.; Xu, T.; Zhang, Q.; Wu, F.; Ma, C.; Liu, B.; Chang J.; Li, X. J. Org. Chem. 2017, 82, 9877-9884.

2) (a) Koca, M.; Yerdelen, K. O.; Anil, B.; Kasap, Z.; Sevindik, H.; Ozyurek, I.; Gunesacar, G.; Turkaydin, K. J. Enzyme Inhib. Med. Chem. 2016, 31, 13-23. (b) Banothu, J.; Basavoju, S.; Bavantula, R. J. Heterocyclic Chem. 2015, 52, 853 - 860. (c) El-Sheshtawy, H. S.; Baker, A. M. A. J. Mol. Struct. 2014, 1067, 225-232. (d) Kahlon, A. K.; Negi, A. S.; Kumari, R.; Srivastava, K. K.; Kumar, S.; Darokar, M. P.; Sharma, A. Appl. Microbiol. Biotechnol. 2014, 98, 2041-2051. (e) Li, Y.; Yan, X.; Chen, D.; Shun, L. Chin. J. Org. Chem. 2013, 33, 14901495. (f) Liedtke, A. J.; Crews, B. C.; Daniel, C. M.; Blobaum, A. L.; Kingsley, P. J.; Ghebreselasie, K.; Marnett, L. J. J. Med. Chem. 2012, 55, 2287-2300.

3) (a) Majetich, G.; Shimkus, J. M. J. Nat. Prod. 2010, 73, 284-298. (b) Huang, K.-S.; Wang, Y.-H.; Li, R.-L.; Lin, M. Phytochemistry 2000, 54, 875-881. (c) Wood, J. L.; Pujanauski, B. G; Sarpong, R. Org. Lett. 2009, 11, 3128-3131. (d) Oh, D.-C.; Williams, P. G.; Kauffman, C. A.; Jensen, P. R.; Fenical, W. Org. Lett. 2006, 8, 1021-1024. (e) Oda, T.; Ebata, M.; Matsumoto, S.; Urano, S.; Sato, Y. Biol. Pharm. Bull. 1999, 22, 586-589. (f) Luo, Y.; Hong, L.; Wu, J. Chem. Commun. 2011, 47, 5298-5300. (g) Herdman, C. A.; Strecker, T. E.; Tanpure, R. P.; Chen, Z.; Winters, A.; Gerberich, J.; Liu, L.; Hamel, E.; Mason, R. P.; Chaplin, D. J.; Trawick, M. L.; Pinney, K. G.; Med. Chem. Commun. 2016, 7, 2418-2427. (h) Ishiguro, 
Y.; Okamoto, K.; Sakamoto, H.; Sonoda, Y. Biosci. Biotech. Biochem., 1993, 57, 866. (i) Majetich, G.; Shimkus, J. M. Tetrahedron Lett. 2009, 50, 3311-3313.

4) (a) Dang, J.-S.; Wang, W.-W.; Zhao, X.; Nagase, S. Org. Lett. 2014, 16, 170-173. (b) Barrera, E. G.; Stedile, F. C.; de Souza, M. O.; Miranda, M. S. L.; de Souza, R. F.; Bernardo-Gusmao, K. Appl. Catal. A 2013, 462, 1-7. (c) Diesendruck, C. E.; Steinberg, B. D.; Sugai, N.; Silberstein, M. N.; Sottos, N. R.; White, S. R.; Braun, P. V.; Moore, J. S. J. Am. Chem. Soc. 2012, 134, 12446-12449. (d) He, Y.; Li, Y. Phys. Chem. Chem. Phys. 2011, 13, 1970-1983. (e) Seyler, H.; Wong, W. W. H.; Jones, D. J.; Holmes, A. B. J. Org. Chem. 2011, 76, 35513556. (f) He, Y.; Chen, H.-Y.; Hou, J.; Li, Y. J. Am. Chem. Soc. 2010, 132, 1377-2382. (g) He, Y.; Zhao, G.; Peng, B.; Li, Y. Adv. Funct. Mater. 2010, 20, 3383-3389. (h) Xia, Z.-Y.; Zhang, Z.-Y.; Su, J.-H.; Zhang, Q.; Fung, K.-M.; Lam, M.-K.; Li, K.-F.; Wong, W.-Y.; Cheah, K.-W.; Tian, H.; Chen, C. H. J. Mater. Chem. 2010, 20, 3768-3774. (i) Cao, T.; Chen, N.; Liu, G.; Wan, Y.; Perea, J. D.; Xia, Y.; Wang, Z.; Song, B.; Li, N.; Li, X.; Zhou, Y.; Brabec, C. J.; Li, Y. J. Mater. Chem. A , 2017, 5, 10206-10219. (j) Xu, X.; Li, Z.; Wang, Z.; Li, K.; Feng, K.; Peng, Q. Nano Energy 2016, 25, 170-183. (k) Lei, Y.; Liu, Y.; Guo, Y.; Chen, J.; Huang, X.; Gao, W.; Qian, L.; Wu, H.; Liu, M.; Cheng, Y. J. Phys. Chem. C 2015, 119, 2313823148.

5) (a) Leino, R.; Lehmus, P.; Lehtonen, A. Eur. J. Inorg. Chem. 2004, 2004, 3201-3222. (b) Zargarian, D. Coord. Chem. Rev. 2002, 233-234. (c) Alt, H. G.; Köppl, A. Chem. Rev. 2000, 100, 1205-1222. (d) Cadierno, V.; Díez, J. N.; Pilar Gamasa, M.; Gimeno, J.; Lastra, E. Coord. Chem. Rev. 1999, 193-195, 147-205. (e) Coates, G. W.; Waymouth, R. M. Science 1995, 267, 217-219. (f) Halterman, R. L. Chem. Rev. 1992, 92, 965-994. (g) Trost, B. M.; Ryan, M. C. Angew .Chem. Int. Ed. 2017, 56, 2862-2879. (h) Rojo, B.; Peris, E. Eur. J. Inorg. Chem. 2012, 1309-1318.

6) (a) Zhao, J.; Clark, D. A. Org. Lett. 2012, 14, 1668-1671. (b) Zheng, H.; Xie, X.; Yang, J.; Zhao, C.; Jing, P.; Fang, B.; She, X. Org. Biomol. Chem. 2011, 9, 7755-7762. (c) Bhanu Prasad, B. A.; Yoshimoto, F. K.; Sarpong, R. J. Am. Chem. Soc. 2005, 127, 12468-12469. (d) Miki, K.; Ohe, K.; Uemura, S. J. Org. Chem. 2003, 68, 8505-8513.

7) (a) Modern Gold Catalyzed Synthesis; Hashmi, A. S. K., Toste, F. D., Eds.; Wiley-VCH: Weinheim, Germany, 2012. For recent reviews, see: (b) Zhang, B.; Wang, T. Asian J. Org. Chem. 2018, 7, 1758-1783. (c) Pirovano, V. Eur. J. Org. Chem. 2018, 17, 1925-1945. (d) Quach, R.; Furkert, D. P.; Brimble, M. A. Org. Biomol. Chem. 2017, 15, 3098-3104. (e) Pflästerer, D.; Hashmi, A. S. K. Chem. Soc. Rev. 2016, 45, 1331-1367. (f) Zi, W.; Toste, F. D. Chem. Soc. Rev. 2016, 45, 4567- 4589. (g) Zheng, Z.; Wang, Z.; Wang, Y.; Zhang, L. Chem. Soc. Rev. 2016, 45, 4448-4458. (h) Asiri, A. M.; Hashmi, A. S. K. Chem. Soc. Rev. 2016, 45, 4471-4503. (i) Dorel, R.; Echavarren, A. M. Chem. Rev. 2015, 115, 9028-9072. (1) Ranieri, B.; Escofet, I.; Echavarren, A. M. Org. Biomol. Chem. 2015, 13, 7103-7118.

8) (a) Hueber, D.; Teci, M.; Brenner, E.; Matt, D.; Weibel, J.-M.; Pale, P.; Blanc, A. Adv. Synth. Catal. 2018, 360, 2453 - 2459. (b) Marion, N.; Díez-González, S.; de Frémont, P.; Noble, A. R.; Nolan, S. P. Angew. Chem. Int. Ed. 2006, 45, 3647-3650. (c) Dubé, P.; Toste, F. D. J. Am. Chem. Soc. 2006, 128, 12062-12063. (d) Zi, W.; Toste, F. D. J. Am. Chem. Soc. 2013, 135, 12600-12603. (e) Adcock, H. V.; Langer, T.; Davies, P. W. Chem. Eur. J. 2014, 20, 7262 7266. (f) Virumbrales, C.; Suárez-Pantiga, S.; Solas, M.; Fernández-Rodríguez, M. A.; Sanz, R. Org. Biomol. Chem. 2018, 16, 2623-2628. (g) Sanjuán, A. M.; Virumbrales, C.; GarcíaGarcía, P.; Fernández-Rodríguez, M. A.; Sanz, R. Org. Lett. 2016, 18, 1072-1075. (h) 
Martínez, A.; García-García, P.; Fernández-Rodríguez, M. A.; Rodríguez, F.; Sanz, R. Angew. Chem. Int. Ed. 2010, 49, 4633-4637. (i) Guo, J.; Peng, X.; Wang, X.; Xie, F.; Zhang, X.; Liang, G.; Sun, Z.; Liu, Y.; Cheng, M.; Liu, Y. Org. Biomol. Chem. 2018, 16, 9147-9151. (j) Álvarez-Pérez, M.; Frutos, M.; Viso, A.; de la Pradilla, R. F.; de la Torre, M. C.; Sierra, M. A.; Gornitzka, H.; Hemmert, C. J. Org. Chem. 2017, 82, 7546-7554. (k) Nahide, P. D.; Jiménez-Halla, J. O. C.; Wrobel, K.; Solorio-Alvarado, C. R.; Ortiz Alvarado, R.; YahuacaJuárez, B. Org. Biomol. Chem. 2018, 16, 7330-7335. (1) Yin, X.; Mato, M.; Echavarren, A. M. Angew. Chem. Int. Ed. 2017, 56, 14591 -14595. (m) Yu, C.; Ma, X.; Chen, B.; Tang, B.; Paton, R. S.; Zhang, G. Eur. J. Org. Chem. 2017, 1561-1565 and references therein. (n) Bucher, J.; Stçßer, T.; Rudolph, M.; Rominger, F.; Hashmi, A. S. K. Angew. Chem. Int. Ed. 2015, 54, 1666 -1670. (o) For a review, see: Raubenheimer, H. G. ChemCatChem 2015, 7, 1261-1262. (p) Ma, B.; Wu, Z.; Huang, B.; Liu, L.; Zhang, J. Chem. Commun. 2016, 52, 9351-9354. (q) Preinfalk, A.; Misale, A.; Maulide, N. Chem. Eur. J. 2016, 22, 14471 - 14474. (r) Morita, N.; Miyamoto, M.; Yoda, A.; Yamamoto, M.; Ban, S.; Hashimoto, Y.; Tamura, O. Tetrahedron Letters 2016, 57, 4460-4463.

9) For reviews on propargylic esters in gold catalysis, see: (a) Shiroodi, R. K.; Gevorgyan, V. Chem. Soc. Rev. 2013, 42, 4991-5001. (b) Marion, N.; Nolan, S. P. Angew. Chem. Int. Ed. 2007, 46, 2750-2752. (c) Marco-Contelles, J.; Soriano, E. Chem. Eur. J. 2007, 13, 1350-1357. For a discussion on the mechanism, see: (d) Correa, A.; Marion, N.; Fensterbank, L.; Malacria, M.; Nolan, S. P.; Cavallo, L. Angew. Chem. Int. Ed. 2008, 47, 718-721.

10) The Claisen rearrangement of propargyl vinyl ethers leading to allenes has been first reported by Toste: (a) Sherry, B. D.; Toste, F. D. J. Am. Chem. Soc. 2004, 126, 15978-15979. See also: (b) Wang, D.; Gautam, L. N. S.; Bollinger, C.; Harris, A.; Li, M.; Shi, X. Org. Lett. 2011, 13, 2618-2621. (c) Vidhani, D. V.; Cran, J. W.; Krafft, M. E.; Alabugin, I. V. Org. Biomol. Chem. 2013, 11, 1624-1630. (d) Vidhani, D. V.; Krafft, M. E.; Alabugin, I. V. Org. Lett. 2013, 15, 4462-4465.

11) Rinaldi, A.; Petrović, M.; Magnolfi, S.; Scarpi, D.; Occhiato, E. G. Org. Lett. 2018, 20 , 4713-4717.

12) Gold(I)-catalyzed cascade processes in which allene intermediates are generated by formal [3,3]-rearrangement of 5-acyloxy-1,3-enynes have been reported to efficiently provide fivemembered rings fused to other ring systems through a final Nazarov cyclization step, too. (a) Lemière, G.; Gandon, V.; Cariou, K.; Fukuyama, T.; Dhimane, A.-L.; Fensterbank, L.; Malacria, M. Org. Lett. 2007, 9, 2207-2209. (b) Lemière, G.; Gandon, V.; Cariou, K.; Hours, A.; Fukuyama, T.; Dhimane, A.-L.; Fensterbank, L.; Malacria, M. J. Am. Chem. Soc. 2009, 131, 2993-3006. (c) Zhang, L.; Wang, S. J. Am. Chem. Soc. 2006, 128, 1442-1443. (d) Shi, F. Q.; Li, X.; Xia, Y.; Zhang, L.; Yu, Z. X. J. Am. Chem. Soc. 2007, 129, 15503-15512. (e) Congmon, J.; Tius, M. A. Eur. J. Org. Chem. 2018, 2926-2930.

13) (a) Scarpi, D.; Faggi, C.; Occhiato, E. G. J. Nat. Prod. 2017, 80, 2384-2388. (b) Scarpi, D.; Petrović, M.; Fiser, B.; Gómez-Bengoa, E.; Occhiato, E. G. Org. Lett. 2016, 18, 3922-3925. (c) Petrović, M.; Scarpi, D.; Fiser, B.; Gómez-Bengoa, E.; Occhiato, E. G. Eur. J. Org. Chem. 2015, 3943-3956.

14) (a) Garayalde, D.; Gómez-Bengoa, E.; Huang, X.; Goeke, A.; Nevado, C. J. Am. Chem. Soc. 2010, 132, 4720-4730. (b) Grissom, J.; Klingberg, D.; Huang, D.; Slattery, B. J. J. Org. Chem. 1997, 62, 603-626. 
15) Propargylic alcohols 5 were either commercially available or prepared by Sonogashira coupling of substituted bromo- and iodobenzenes with the requisite alkynol (see Experimental Section).

16) For a review on the synthesis of vinyl ethers, see: Winternheimer, D. J.; Shade, R. E.; Merlic, C. A. Synthesis 2010, 2497-2511.

17) Lin, M.; Liu, X.-T.; Chen, Q.-Z.; Wu, F.; Yan, P.; Xu, S.-X.; Chen, X.-L.; Wen, J.-J.; Zhan, Z.-P. Synlett 2011, 665-670.

18) Dulcère, J.-P.; Rodriguez, J. Synthesis, 1993, 399-405.

19) Allene 9a undergoes degradation during chromatography and it was characterized as crude reaction mixture. Diagnostic ${ }^{1} \mathrm{H}$ NMR signals are the doublet at $1.81 \mathrm{ppm}$ of the methyl group which couples with allene proton resonating at $5.62 \mathrm{ppm}$ as a quartet of triplet (due to a long range coupling with the $\mathrm{CH}_{2}$ group). The proton of the carbonyl group is a triplet at $9.74 \mathrm{ppm}$. See Experimental Section and also Supporting Information for NMR spectra.

20) For reviews on NHC ligands for gold(I) catalysis, see: (a) Gatineau, D.; Goddard, J.-P.; Mouriès-Mansuy, V.; Fensterbank, L. Isr. J. Chem. 2013, 53, 892 - 900. (b) Marion, N.; Nolan, S. P. Chem. Soc. Rev. 2008, 37, 1776-1782.

21) IPr is a weaker ligand than the corresponding saturated SIPr and therefore could leave the metal center more electron poor than its saturated congener. Consequently, its metal complexes could be more reactive in activating unsaturations toward nucleophilic attacks. Fantasia, S.; Petersen, J. L.; Jacobsen, H.; Cavallo, L.; Nolan, S. P. Organometallics 2007, 26, 5880-5889.

22) For this reason aldehyde 8a was characterized as crude reaction mixture. Diagnostic ${ }^{1} \mathrm{H}$ NMR signals are the quartet at $3.53 \mathrm{ppm}$ for the proton at $\mathrm{C} 1$ which couples with the methyl at the same position and which resonates as a doublet at $1.33 \mathrm{ppm}$. 2-H is a singlet at $6.40 \mathrm{ppm}$ and the $\mathrm{CHO}$ proton is found a $9.79 \mathrm{ppm}$ as a triplet. See Experimental Section and also Supporting Information for NMR spectra.

23) (a) The structure of isomer $\mathbf{1 0 f}$ was assigned on the basis of the chemical shift and coupling constants of aromatic protons. The two protons ortho to the methoxy group (at positions 4 and 6) are shielded and resonate below $7.00 \mathrm{ppm}$. The $4-\mathrm{H}$ is a doublet at $6.87 \mathrm{ppm}$ with a very small ${ }^{4} J$ with the proton at position $6(0.6 \mathrm{~Hz})$ and the latter is a doublet of doublet at 6.77 ppm with a larger vicinal coupling constant $(8 \mathrm{~Hz})$ with $7-\mathrm{H}$ which resonates as a doublet at $7.29 \mathrm{ppm}$. (b) The ratio between the 5-F and 7-F isomers was 85:15 in the crude reaction mixture. The structure of major isomer $\mathbf{1 0 k}$ was assigned (for both double bond isomers) on the basis of the chemical shift and coupling constants of aromatic protons. The two protons ortho to the $\mathrm{F}$ atom at $\mathrm{C} 4$ and $\mathrm{C} 6$ resonates as dd $\left({ }^{3} \mathrm{~J}_{\mathrm{HF}}=8.8 \mathrm{~Hz}\right.$ and $\left.{ }^{4} \mathrm{~J}_{\mathrm{HH}}=2.4 \mathrm{~Hz}\right)$ and ddd $\left({ }^{4} J_{\mathrm{HH}}=2.4 \mathrm{~Hz},{ }^{3} J_{\mathrm{HH}}=8.4 \mathrm{~Hz},{ }^{3} J_{\mathrm{HF}}=8.7 \mathrm{~Hz}\right.$, $)$, respectively. The proton at $\mathrm{C} 7$ resonates instead as a dd $\left({ }^{4} J_{\mathrm{HF}}=5.2 \mathrm{~Hz}\right.$ and $\left.{ }^{3} J_{\mathrm{HH}}=8.4 \mathrm{~Hz}\right)$.

24) The structure of compound $\mathbf{1 0 i}$ was assigned by analysis of ${ }^{1} \mathrm{H},{ }^{13} \mathrm{C}$ and bidimensional NMR spectra (gCOSY and gHSQC) (see Supporting Information). Diagnostic ${ }^{1} \mathrm{H}$ NMR signals (in $\mathrm{CDCl}_{3}$ ) are the triplet at $5.19 \mathrm{ppm}$ for the proton of the dioxolane moiety which couples with the side chain $\mathrm{CH}_{2}$ group at $\mathrm{C} 3$, which in turn is a doublet at $2.90 \mathrm{ppm}$ The benzylic protons at $\mathrm{C} 6$ is a doublet at $4.73 \mathrm{ppm}$ for the coupling with the proton of the hydroxyl group.

25) In some cases we observed a slow isomerization in $\mathrm{CDCl}_{3}$ (for example when recording ${ }^{13} \mathrm{C}$ NMR spectra overnight) and in such cases we used $\mathrm{CD}_{3} \mathrm{OD}$ as the solvent for the characterization. 
26) DFT calculations were carried out with the Gaussian16 set of programs and the M06 functional. For computational details, see the Supplementary Information.

27) Reviews on counterion effects in homogeneous gold catalysis: (a) Jia, M.; Bandini, M. ACS Catal. 2015, 5, 1638-1652. (b) Schieß1, J.; Schulmeister, J.; Doppiu, A.; Wçrner, E.; Rudolph, M.; Karch, R.; Hashmi, A. S. K. Adv. Synth. Catal. 2018, 360, 2493-2502. See also, (c) Lu, Z.; Han, J.; Okoromoba, O. E.; Shimizu, N.; Amii, H.; Tormena, C. F.; Hammond, G. B.; Xu, B. Org. Lett. 2017, 19, 5848-5851.

\section{Figure 1}

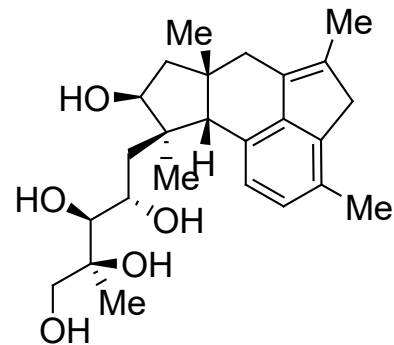

Neomangicol C

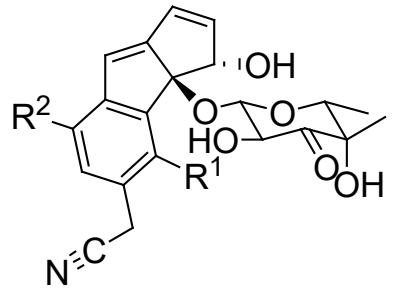

$\mathrm{R}^{1}=\mathrm{Cl} \mathrm{R} \mathrm{R}^{2}=\mathrm{H}$ Cyanosporaside $\mathrm{A}$ $\mathrm{R}^{1}=\mathrm{H} \mathrm{R}^{2}=\mathrm{Cl}$ Cyanosporaside $\mathrm{B}$<smiles></smiles>

Indeno[1,2-c]chromene $\mathrm{R}^{1}=\mathrm{R}^{3}=\mathrm{H}$ $\mathrm{R}^{2}=\mathrm{R}^{4}=\mathrm{C}_{6} \mathrm{H}_{5}$<smiles>[R]c1c(OC)ccc2c1CC=C2c1cc(OC)c(OC)c(OC)c1</smiles><smiles>COc1ccc2c(c1)C(=O)CC2OC</smiles>

$\mathrm{R}=\mathrm{OMe}, \mathrm{H}, \mathrm{OH}$<smiles>CC(C)c1c(O)c(O)c2c(c1O)C=C1C(C)(C)CCC[C@]1(C)C2</smiles>

Dichronal B<smiles>COc1c(O)c2c(c(O)c1C(C)C)C(C)=C1C(C)(C)CCC[C@]1(C)C2=O</smiles>

Taiwaniaquinol D<smiles>[R2]Oc1ccc(C2=C(CC)c3ccc([R2])cc3C2C)cc1</smiles>

Indenistrol

$\mathrm{R}^{1}=\mathrm{R}^{2}=\mathrm{H}$

$\mathrm{R}^{1}=\mathrm{Me} \mathrm{R}^{2}=\mathrm{H}$ 


\section{Scheme 1}

(a) Previous work: tandem gold(I)-catalyzed Claisen rearrangement/Nazarov reaction<smiles>[Y10][C@H](C)[C@H](C)OC=C</smiles>

(b) This work: tandem gold(I)-catalyzed Claisen rearrangement/hydroarylation reaction<smiles>C=COC(C)C#Cc1ccccc1</smiles>

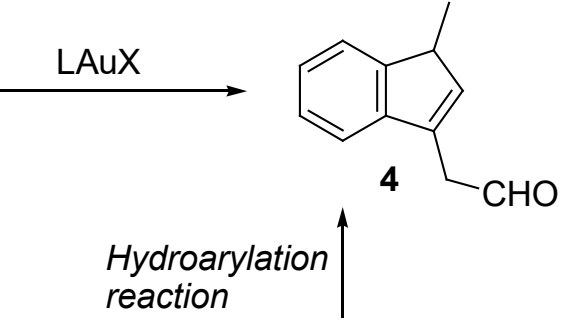

and/or<smiles>CC=C(CC)C(CC=O)c1ccccc1</smiles> 


\section{Scheme 2}
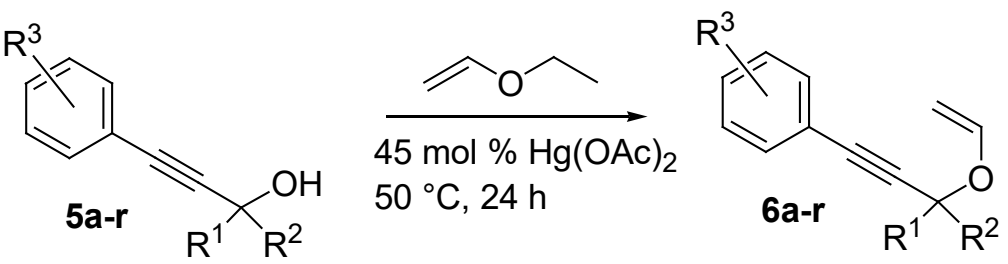

6a $R^{1}=M e, R^{2}=R^{3}=H$

6b $\mathrm{R}^{1}=\mathrm{Me}, \mathrm{R}^{2}=\mathrm{H}, \mathrm{R}^{3}=p-\mathrm{Me}$

6c $R^{1}=M e, R^{2}=H, R^{3}=o-M e$

6d $\mathrm{R}^{1}=\mathrm{Me}, \mathrm{R}^{2}=\mathrm{H}, \mathrm{R}^{3}=m-\mathrm{Me}$

6e $\mathrm{R}^{1}=\mathrm{Me}, \mathrm{R}^{2}=\mathrm{H}, \mathrm{R}^{3}=p-\mathrm{MeO}$

6f $\mathrm{R}^{1}=\mathrm{Me}, \mathrm{R}^{2}=\mathrm{H}, \mathrm{R}^{3}=m-\mathrm{MeO}$

6g $\mathrm{R}^{1}=\mathrm{Me}, \mathrm{R}^{2}=\mathrm{H}, \mathrm{R}^{3}=p-\mathrm{CH}_{2} \mathrm{NHBoc}$

6h $\mathrm{R}^{1}=\mathrm{Me}, \mathrm{R}^{2}=\mathrm{H}, \mathrm{R}^{3}=p-\mathrm{CH}_{2} \mathrm{OBn}$

6i $\mathrm{R}^{1}=\mathrm{Me}, \mathrm{R}^{2}=\mathrm{H}, \mathrm{R}^{3}=p-\mathrm{CH}\left(-\mathrm{OCH}_{2} \mathrm{CH}_{2} \mathrm{O}-\right)$ 6j $\mathrm{R}^{1}=\mathrm{Me}, \mathrm{R}^{2}=\mathrm{H}, \mathrm{R}^{3}=p-\mathrm{Br}$

6k $\mathrm{R}^{1}=\mathrm{Me}, \mathrm{R}^{2}=\mathrm{H}, \mathrm{R}^{3}=m-\mathrm{F}$

6I $\mathrm{R}^{1}=\mathrm{Me}, \mathrm{R}^{2}=\mathrm{H}, \mathrm{R}^{3}=p-\mathrm{CO}_{2} \mathrm{Me}$

$6 \mathrm{~m} \mathrm{R}^{1}=n-\mathrm{Pr}, \mathrm{R}^{2}=\mathrm{R}^{3}=\mathrm{H}$

6n $\mathrm{R}^{1}=\mathrm{Bn}, \mathrm{R}^{2}=\mathrm{R}^{3}=\mathrm{H}$

6o $R^{1}=R^{2}=M e, R^{3}=H$

$6 \mathrm{p} \mathrm{R}^{1}=\mathrm{Me}, \mathrm{R}^{2}=i-\mathrm{Bu}, \mathrm{R}^{3}=\mathrm{H}$

6q $R^{1}=P h, R^{2}=R^{3}=H$

$6 r \mathrm{R}^{1}=m, p-\mathrm{Cl}_{2} \mathrm{C}_{6} \mathrm{H}_{3}, \mathrm{R}^{2}=\mathrm{R}^{3}=\mathrm{H}$

\section{Scheme 3}

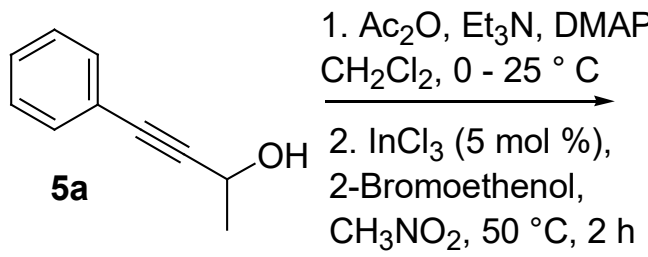

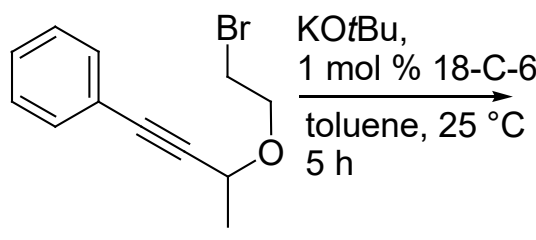

7a (78\%, two steps)

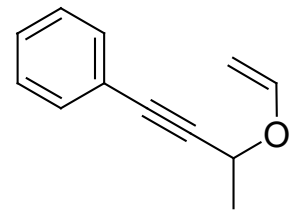

6a $(91 \%)$ 


\section{Scheme 4}

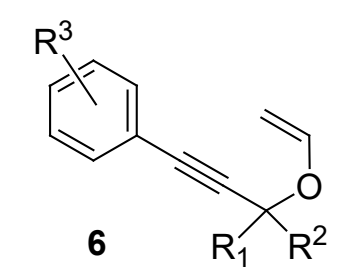

a) $3 \mathrm{~mol} \%\left[\mathrm{IPrAu}^{+} \mathrm{BF}_{4}^{-}\right.$
DCM, $25^{\circ} \mathrm{C}$
b) $\mathrm{NaBH}_{4}, \mathrm{MeOH}$

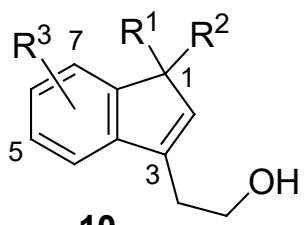

10

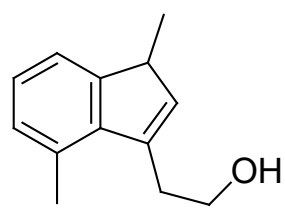

10c (1.5 h, 71\%)<smiles>CC1C=C(CCO)c2ccc(I)cc21</smiles>

$10 \mathrm{e}(0.25 \mathrm{~h}, 79 \%)$ 10d $(0.25 \mathrm{~h}, 77 \%, 1: 1$ mixture)<smiles>COc1ccc2c(c1)C(CCO)=CC2C</smiles><smiles>CC1C=C(CCO)c2ccc(CNC(=O)O)cc21</smiles>

$10 f(0.25 \mathrm{~h}, 74 \%)$

$\log (0.25$ h, 62\%)<smiles>CC1C=C(CC2OCCO2)c2ccc(CO)cc21</smiles><smiles>CC1C=C(CCO)c2ccc(Br)cc21</smiles>

10j $(6 \mathrm{~h}, 56 \%)$<smiles>CCCC1C=C(CCO)c2ccccc21</smiles>

$10 \mathrm{~m}(1 \mathrm{~h}, 70 \%)^{a}$

10I $(7 \mathrm{~h}, 72 \%)^{d}$

(ca. $1: 1$ mixture)<smiles>CC1(C)C=C(CCO)c2ccccc21</smiles><smiles>CC(C)CC1(C)C=C(CCO)c2ccccc21</smiles>

$100(3.5$ h, 93\%)<smiles>CC1C=C(CCO)c2ccc(COc3ccccc3)cc21</smiles>
10h $(0.8 \mathrm{~h}, 75 \%)^{\mathrm{a}}$<smiles>CC1=C=C(CCO)c2cc(F)ccc21</smiles>
10k $(16 \mathrm{~h}, 74 \%)^{\mathrm{c}}$ (1.2: 1 mixture)<smiles>OCCC1=CC(Cc2ccccc2)c2ccccc21</smiles>
10n $(2 \mathrm{~h}, 69 \%)^{a, b}$

${ }^{a}$ Commercial [IPrAuCH${ }_{3} \mathrm{CN}_{\mathrm{BBF}}{ }_{4}$ was used; ${ }^{b} 6 \mathrm{Mol} \%$ of the catalyst was used; ${ }^{c}$ In mixture with $7-\mathrm{F}$ isomer (15\%); ${ }^{d}$ Reaction carried out at $40{ }^{\circ} \mathrm{C}$ 


\section{Scheme 5}

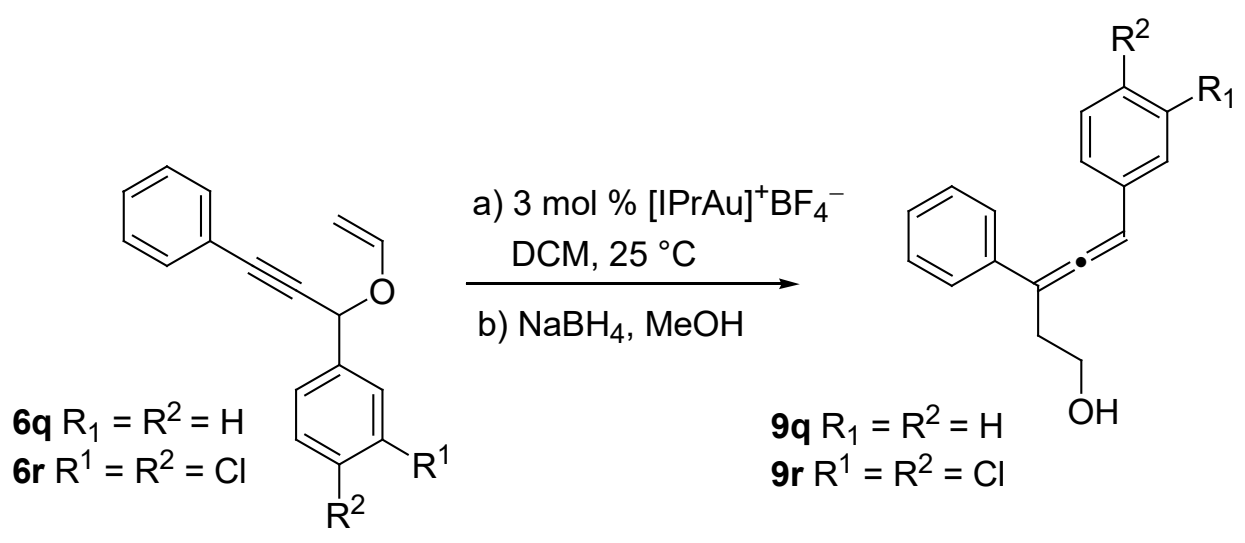




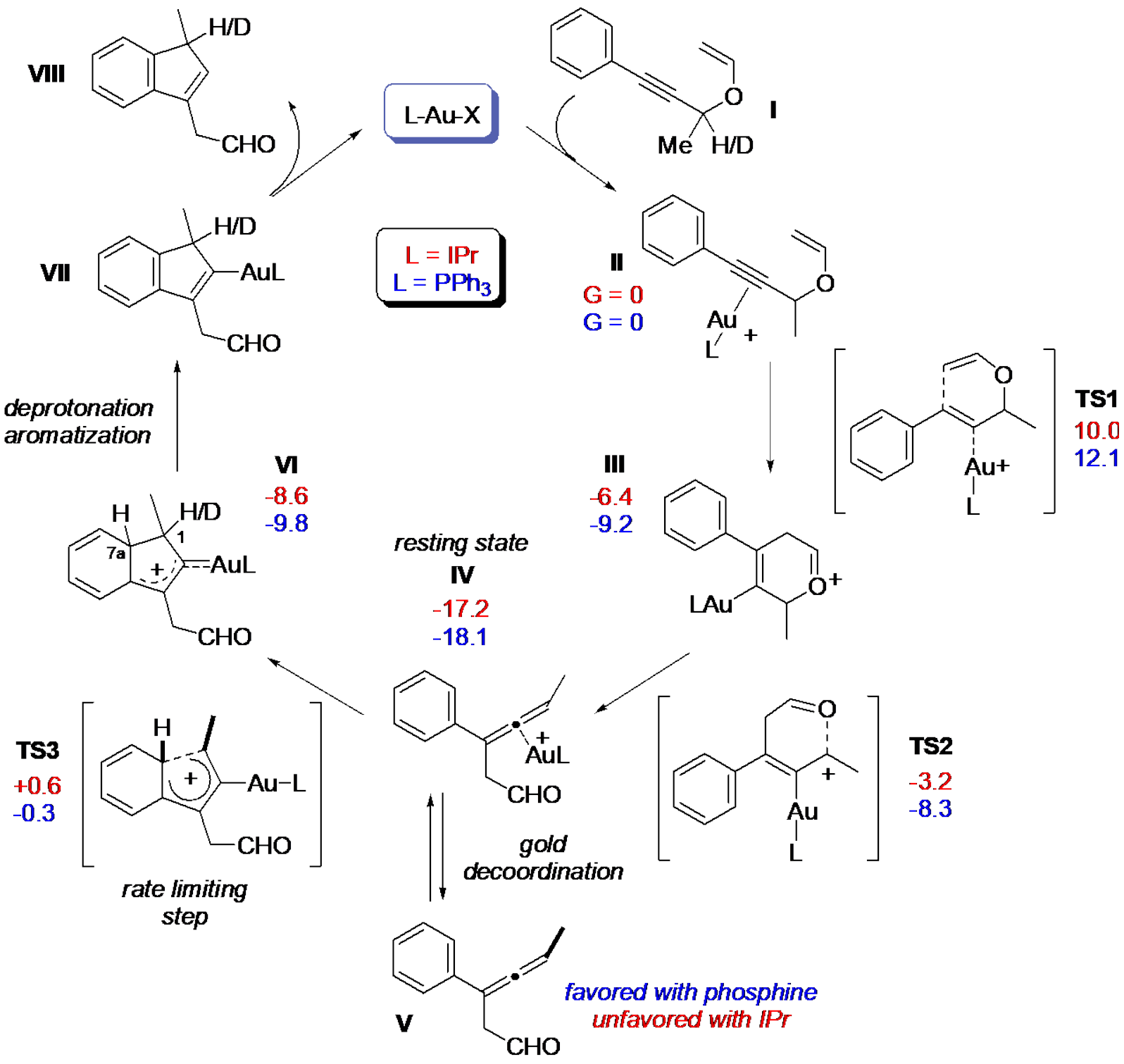

Schematic representation of the thermodynamics associated with the tandem process.

Energies in $\mathrm{kcal} / \mathrm{mol}$ are calculated relative to II (in blue for $\mathrm{Ph}_{3} \mathrm{P}$ ligand, in red for IPr ligand) 
Scheme 7
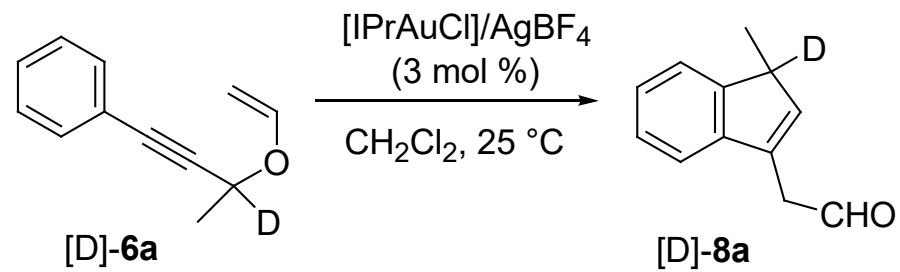

[D]-8a

$(100 \%)$

Scheme 8

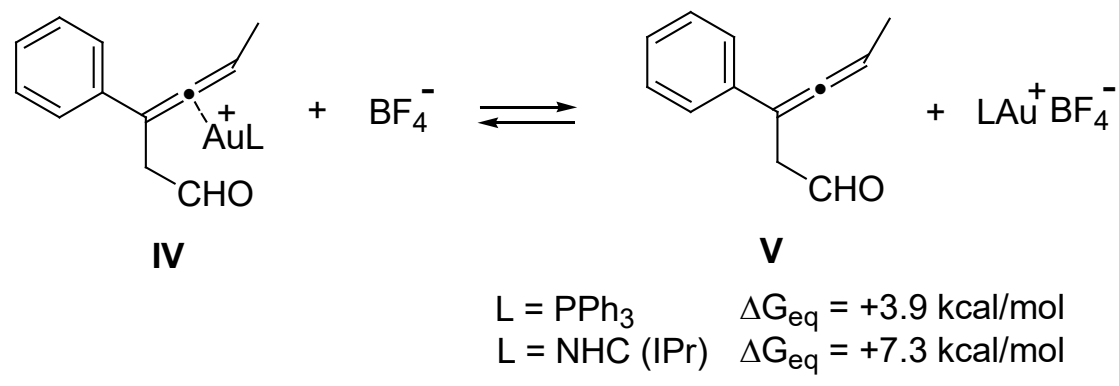

Scheme 9.

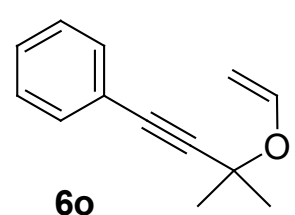

60

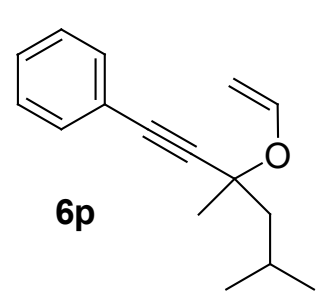

a) $3 \mathrm{~mol} \%[\mathrm{IPrAu}]^{+} \mathrm{BF}_{4}{ }^{-}$ LCM, $25^{\circ} \mathrm{C}$

b) DCM/THF, $0^{\circ} \mathrm{C}$ $\mathrm{Ph}_{3} \mathrm{P}=\mathrm{O}_{13}^{\mathrm{O}}$

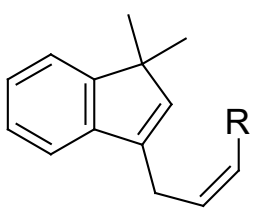

$11 \mathrm{R}=\mathrm{H}(70 \%)$ $12 \mathrm{R}=n$-Pentyl $(80 \%)$<smiles>CC(C)CC1(C)C=C(C/C=C\CC2OCCO2)c2ccccc21</smiles>

$14(71 \%)$ 